\title{
Thermodynamic and geochemical modeling of assimilation in primitive magma systems
}

\author{
J. S. Heinonen* and V. J. Virtanen \\ Department of Geosciences and Geography, University of Helsinki, Helsinki, Finland \\ *Corresponding author e-mail: jussi.s.heinonen@helsinki.fi
}

\begin{abstract}
Summary During few recent decades, a surge in thermodynamically controlled geochemical models for igneous systems has occurred. These provide considerable potential to study the evolution of economically important primitive open magma systems, including layered intrusions. Here we provide an overview of the recent findings of the PALIN-research project based at the University of Helsinki that utilizes such tools for studying various magmatic settings. The findings indicate that assimilation of wall-rocks, often crucial to ore formation, is a complex and selective process and can have unforeseen consequences related to geochemical evolution of primitive magmas. We further consider future challenges related to modeling and understanding of intrusive open systems.
\end{abstract}

\section{Introduction and background to current research}

In order to understand and constrain the geochemical evolution of an igneous open system, knowledge on the thermodynamic properties and constraints of the system and its phases are required. The traditional binary mixing and assimilation-fractional crystallization (AFC; DePaolo, 1981) models overlook many aspects of the assimilation processes that are critical to ore formation processes. Recent advancements in harnessing the information gathered from experimental petrology (e.g., Ariskin et al., 1993, 2018; Ghiorso and Sack, 1995; Gualda et al., 2012; Bohrson et al., 2014, 2020; Heinonen et al., 2020) have resulted in the generation of modeling tools that can be used to provide such information and constraints (Fig. 1). Using such tools, in turn, leads to more refined models and better control on the geochemical signatures that may be the result of assimilation processes potentially relevant for ore deposition.

\section{Research questions at hand}

The current research of our group is funded by the Academy of Finland from September 2016 to August 2021 and is named "Partial melting processes in the contact zones of layered intrusions (PALIN); https://blogs.helsinki.fi/jsheinon/". The project focuses on two research areas: 1) the development and application of thermodynamic models to layered - and other mafic and also more siliceous - intrusions and 2) partial melting experiments on wall-rocks of layered intrusions (namely black shale; see Virtanen and Heinonen, this volume, for more information).

The focus area 1 is managed in collaboration with the Colorado School of Mines (USA) and the University of California Santa Barbara (USA) and relies on a freely available modeling tool called Magma Chamber Simulator (MCS; Bohrson et al., 2014, 2020; Heinonen et al., 2020; Fig. 1; https://mcs.geol.ucsb.edu/). The MCS utilizes the experimentally calibrated MELTS-family of algorithms (rhyolite-MELTS or pMELTS; REFS). It uses these algorithms (MELTS-engines) to study the phase equilibria and geochemical evolution of the crystallizing resident magma, wall-rock that is heated and potentially melted and assimilated by the magma either as stoped blocks of batches of partial melt, and possible recharge magmas $\left(\mathrm{R}_{\mathrm{n}} \mathrm{AS}_{\mathrm{n}} \mathrm{FC}\right.$ system; Fig. 1; see Bohrson et al., 2020). The evolution of the modeled system is controlled by 
user-input parameters that can then be varied to find the best and most fitting models for the studied natural system (forward modeling). These best-fit models have potential to reveal evolutionary scenarios and provide thermodynamic and geochemical constraints that would have otherwise remained hidden.

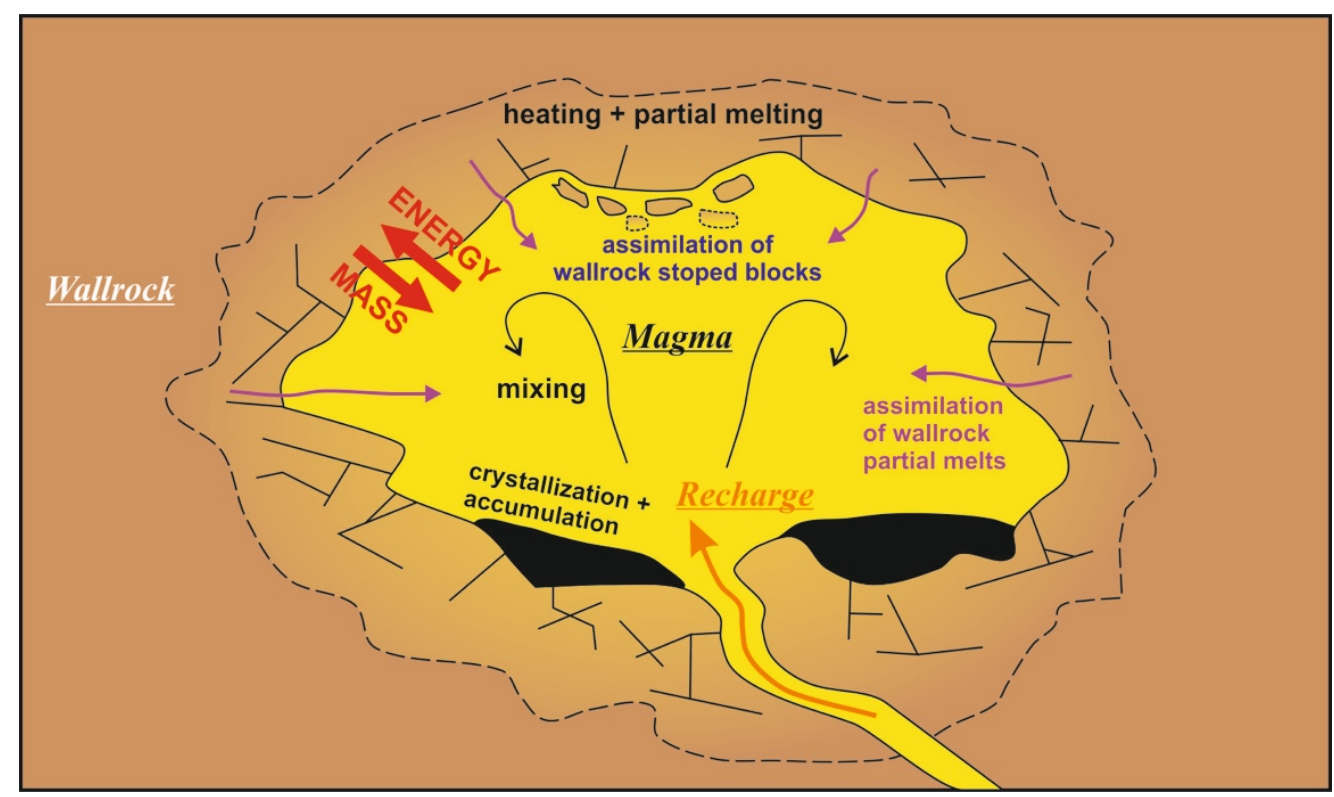

Figure 7. The processes that Magma Chamber Simulator handles using thermodynamic and compositional constraints. Three subsystems (resident magma, wall-rock, and recharge magma) are underlined.

Our research has and is revealing several important aspects of primitive magmatism and assimilation. In the context of ore formation and prospecting, the assimilation capacity of parental magmas, the onset and span of assimilation, and resulting geochemical signatures are key parameters. For example, primitive igneous systems have considerable thermodynamic potential to assimilate crustal rocks, even basalts (Heinonen et al., in press). Very recent modeling with MCS suggests that some komatiitic melts have thermodynamic potential to assimilate even more than their own weight of partial melts of silicate crust. This can have important implications for the generation of, for example, siliceous high-Mg basalts in the Proterozoic (Fig. 2). Assimilation is not only limited to assimilating partial melts of the wallrocks, but hot magmas can also dissolve notable amounts of wall-rock, including more primitive floor cumulate layers of the cogenetic magmatic system (Latypov et al., 2021, see also Yao et al., 2021). On the other hand, even minor assimilation of partial melts of felsic crustal wallrocks, considerably enriched in incompatible trace elements, by primitive magmas may have notable effects on their geochemistry (Heinonen et al., 2019). Assimilation of "barren" wallrocks may also dilute the magma from economically important components and thus prohibit ore formation (Virtanen et al., 2021). In addition to these examples, the ongoing research tries to find a parental magma candidate for the 2.5-2.4 Ga layered intrusions of Fennoscandia and constrain their deep crustal evolution before emplacement to upper crustal levels. 


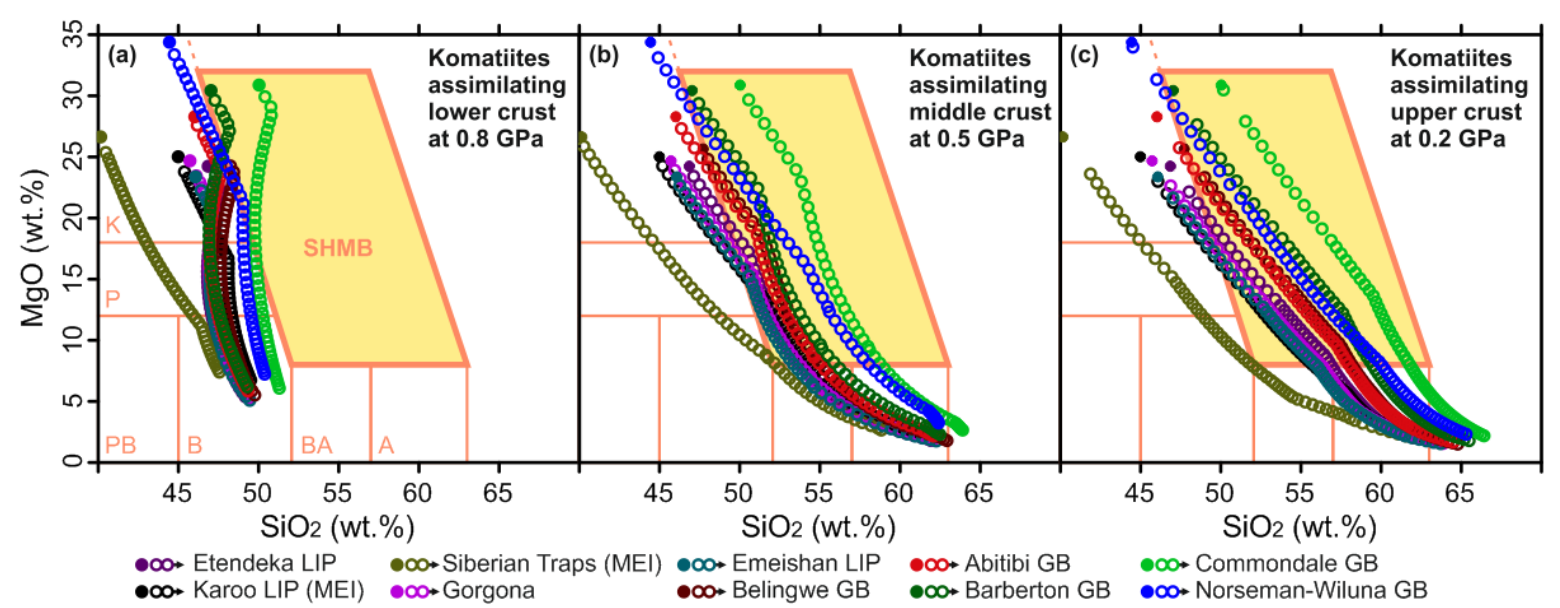

Figure 2. The results of the Magma Chamber Simulator AFC models for various komatiitic melts shown in $\mathrm{SiO}_{2}$ vs. $\mathrm{MgO}$ diagrams overlain with relevant portions of boninite classification of Pearce and Reagan (2019). Parental melt is marked with a closed symbol - every open symbol marks an assimilation step of wall-rock $(\mathrm{a}=$ lower crust, $\mathrm{b}=$ middle crust, $\mathrm{c}=$ upper crust) partial melt in the thermodynamically controlled assimilation model. Abbreviations of the classification shown in a: $\mathrm{K}=$ komatiite, $\mathrm{P}=$ picrite, $\mathrm{PB}=$ picrobasalt, $\mathrm{B}=$ basalt, $\mathrm{BA}=$ basaltic andesite, $\mathrm{A}=$ andesite, $\mathrm{SHMB}=$ siliceous high-Mg basalt (highlighted).

\section{Future prospects}

Something that is missing from the thermodynamic models, are kinetic constraints. In the future, we also need to better consider and combine such information with the thermodynamic and geochemical modeling. There is increasing amount of evidence that many magma systems parental to layered intrusions were dynamic and composed of complex sill and magma mush systems instead of being "box-like" magma chambers in the traditional sense (for recent studies related to Bushveld Igneous Complex, South Africa, by Scoates et al. (in press) and Yao et al. (2021)). In such magmatic environments, the dynamics and the kinetics - not just thermodynamics - of the system become critical for its evolution.

Even given these limitations, thermodynamically constrained geochemical models of open igneous systems are a significant leap forward from the traditional binary mixing and AFC modeling. In addition, they provide good approximations on the overall effects of assimilation processes, regardless of local variations in magma dynamics and kinetic factors. Our and other groups' findings have generated an emerging view of magmatic systems that have potential to assimilate significant amount of wall-rock and, on the other hand, be considerably influenced by only small-additions of wall-rock or associated fluids and melts. These results call for reconsiderations on the potential geochemical tracers of assimilation processes that are often critical for ore formation. The mass balance of the parental magma and the different phases of assimilated wall-rock is central for this question. For example, some economically promising intrusive candidates showing signs of assimilation of crust by having, for example, high $\mathrm{SiO}_{2}$ and LREE/MREE, could be "barren" due to 1) only minor input of selectively enriched crustal partial melts or 2) wholesale assimilation of large amounts of crust, which could dilute concentrations of elements that have potential for ore formation. The thermodynamic tools have potential to respond to such issues and help in constraining crystallization and assimilation processes in igneous systems. Such tools have been underused in studies of Fennoscandian intrusive systems (for a recent example, see Järvinen et al. 2020). 


\section{Acknowledgements}

We thank our collaborators at the Colorado School of Mines (Wendy Bohrson), Geological Survey of Finland (Ferenc Molnár and Saku Vuori) University of California Santa Barbara (Jenna Adams, Guy Brown, Melissa Scruggs, and Frank Spera), University of Helsinki (Ville Järvinen and Arto Luttinen), and University of Witwatersrand (Sofia Chistyakova and Rais Latypov).

\section{References:}

Ariskin AA, Frenkel MY, Barmina GS, Nielsen RL (1993) Comagmat: a Fortran program to model magma differentiation processes. Comput Geosci 19:1155-1170

Ariskin AA, Bychkov KA, Nikolaev GS, Barmina GS (2018) The COMAGMAT-5: Modeling the Effect of Fe-Ni Sulfide Immiscibility in Crystallizing Magmas and Cumulates. J Petrol 59:283-298

Bohrson WA, Spera FJ, Ghiorso MS, Brown GA, Creamer JB, Mayfield A (2014) Thermodynamic Model for Energy-Constrained Open-System Evolution of Crustal Magma Bodies Undergoing Simultaneous Recharge, Assimilation and Crystallization: the Magma Chamber Simulator. J Petrol 55:1685-1717

Bohrson WA, Spera FJ, Heinonen JS, Brown GA, Scruggs MA, Adams JV, Takach MK, Zeff G, Suikkanen E (2020) Diagnosing open-system magmatic processes using the Magma Chamber Simulator (MCS): part I-major elements and phase equilibria. Contrib Mineral Petrol 175:104

DePaolo DJ (1981) Trace element and isotopic effects of combined wallrock assimilation and fractional crystallization. Earth Planet Sci Lett 53:189-202

Ghiorso MS, Sack RO (1995) Chemical mass transfer in magmatic processes IV. A revised and internally consistent thermodynamic model for the interpolation and extrapolation of liquid-solid equilibria in magmatic systems at elevated temperatures and pressures. Contrib Mineral Petrol 119:197-212

Gualda GAR, Ghiorso MS, Lemons RV, Carley TL (2012) Rhyolite-MELTS: a Modified Calibration of MELTS Optimized for Silica-rich, Fluid-bearing Magmatic Systems. J Petrol 53:875-890

Heinonen JS, Luttinen AV, Spera FJ, Bohrson WA (2019) Deep open storage and shallow closed transport system for a continental flood basalt sequence revealed with Magma Chamber Simulator. Contrib Mineral Petrol 174:87

Heinonen JS, Bohrson WA, Spera FJ, Brown GA, Scruggs MA, Adams JV (2020) Diagnosing open-system magmatic processes using the Magma Chamber Simulator (MCS): part II-trace elements and isotopes. Contrib Mineral Petrol 175:105

Heinonen JS, Luttinen AV, Spera FJ, Vuori SK, Bohrson WA (in press) Archean crust as the main course, basalt for dessert - a record of two serial contamination events in $\sim 180$ Ma gabbroic dikes in Antarctica. Contrib Mineral Petrol

Järvinen V, Halkoaho T, Konnunaho J, Heinonen JS, Rämö OT (2020) Parental magma, magmatic stratigraphy, and reef-type PGE enrichment of the 2.44-Ga mafic-ultramafic Näränkävaara layered intrusion, Northern Finland. Miner Deposita 55:1535-1560

Latypov R, Heinonen JS, Chistyakova S (2021) Thermodynamic constraints on assimilation of floor cumulates by superheated basaltic-andesitic melts in the Bushveld Complex, South Africa. In: Kukkonen I, Veikkolainen T, Heinonen S, et al. (eds), Lithosphere 2021 - Eleventh symposium on structure, composition and evolution of the lithosphere: programme and extended abstracts. Institute of Seismology, University of Helsinki, report s-71:73-76 (manuscript in preparation)

Pearce JA, Reagan MK (2019) Identification, classification, and interpretation of boninites from Anthropocene to Eoarchean using Si-Mg-Ti systematics. Geosphere 15:1008-1037

Scoates JS, Wall CJ, Friedman RM, Weis D, Mathez EA, VanTongeren JA (in press) Dating the Bushveld Complex: Timing of Crystallization, Duration of Magmatism, and Cooling of the World's Largest Layered Intrusion and Related Rocks. J Petrol

Virtanen VJ, Heinonen JS (2021) The effects of assimilation on sulfide saturation and the formation of noritehosted Cu-Ni deposits in the Duluth Complex, Minnesota. In: Kukkonen I, Veikkolainen T, Heinonen S, et al. (eds), Lithosphere 2021 - Eleventh symposium on structure, composition and evolution of the lithosphere: programme and extended abstracts. Institute of Seismology, University of Helsinki, report s71:147-150 (manuscript in preparation)

Virtanen VJ, Heinonen JS (this volume) Assimilation of sulphur-bearing black shale and its effects on the formation of magmatic $\mathrm{Cu}-\mathrm{Ni}$ deposits - the essential role of devolatilization fluids

Yao Z, Mungall JE, Jenkins MC (2021) The Rustenburg Layered Suite formed as a stack of mush with transient magma chambers. Nature Communications 12:505 